\title{
Pengelolaan hutan bersama pemerintah dan unsur-unsur yang ada di masyarakat dalam menjaga kawasan hutan \\ NURUL FATHANA K. \\ 105611120216
}

\section{UNIVERSITAS MUHAMMADIYAH MAKASSAR}

Pengelolaan lingkungan membutuhkan perhatian banyak pihak karena yang merasakan dampak masalah lingkungan adalah semua unsur baik pemerintah, swasta, maupun masyarakat. Pemerintah melalui regulasi yang mereka jalankan diharapkan dapat memberikan dukungan perbaikan lingkungan. Sementara pihak swasta melalui CSR memberikan perhatian terhadap lingkungan yang ada di sekitar wilayah operasional mereka dan masyarakat berperan dalam partisipasi perbaikan lingkungan dan juga kerlibatan LSM dalam hal fungsi kontrol sosialnya terhadap lingkungan. Kerlibatan semua unsur inilah yang dapat mengarahkan pada tata kelola kolaboratif atau Collaborative Governance yaitu proses keterlibatan sejumlah stakeholder yang memiliki kepentingan bersama dan memiliki tujuan yang ingin dicapai bersama.Ansell dan Gash (2007), melihat Collaborative Governance sebagai sebuah pengaturan yang mengatur satu atau lebih lembaga secara langsung terlibat secara kolektif dengan tujuan yang sama. Balogh (2011),juga melihat Collaborative Governance merupakan sebuah prosesdalam manejemen dan perumusan keputusan yang berhubungan dengan kepentingan publik. Proses ini dilaksanakan dengan cara melibatkan aktor-aktor dari berbagai level untukberperan dalam pengelolaan lingkungan secara kolektif guna tercapainya pembangunan yang berwawasan lingkungan (Nahruddin, 2018).

Hutan merupakan bagian integral dan tidak terpisahkan dari kehidupan masyarakat yang hidup di sekitarnya. Hubungan interaksi antara masyarakat desa hutan dengan lingkungan alam sekitarnya telah berlangsung selama berabad-abad lamanya secara lintas generasi dalam bingkai keseimbangan kosmos. Pengelolaan dan pemanfaatan sumberdaya hutan di setiap masyarakat desa hutan mempunyai ciri khas tersendiri (local spesific) sesuai dengan karakteristik budaya masyarakat yang tinggal di dalam dan sekitar hutan. Sumberdaya hutan dimaknai sebagai sumberdaya alam yang memiliki nilai ekonomi, religius, politik, sosial dan budaya. Oleh karena itu, kelangsungan hidup dari masyarakat dan hutan sangat tergantung dari ketersediaan sumberdaya hutan yang ada di sekitar lingkungannya (Nugraha, 2005:11)

Pengelolaan Hutan Bersama Masyarakat adalah sistem pengelolaan sumberdaya hutan dengan pola kolaborasi yang bersinergi antara Perum Perhutani dan masyarakat desa hutan atau para pihak yang berkepentingan dalam upaya mencapai keberlanjutan fungsi dan manfaat sumberdaya hutan yang optimal dan peningkatan IPM yang bersifat fleksibel, partisipatif dan akomodatif. PHBM dimaksudkan untuk memberikan arah pengelolaan sumberdaya hutan dengan 
memadukan aspek ekonomi, ekologi dan sosial secara proporsional dan profesional. PHBM bertujuan untuk meningkatkan peran dan tanggung jawab Perum Perhutani, masyarakat desa hutan dan pihak yang berkepentingan terhadap keberlanjutan fungsi dan manfaat sumberdaya hutan, melalui pengelolaan sumberdaya hutan dengan model kemitraan. PHBM dilaksanakan di dalam dan di luar kawasan hutan dengan mempertimbangkan skala prioritas berdasarkan perencanaan partisipatif. PHBM yang dilaksanakan di dalam kawasan hutan tidak bertujuan untuk mengubah status kawasan hutan, fungsi hutan dan status tanah negara. Para pihak yang dimaksud dalam PHBM adalah pihak di luar Perum Perhutani dan masyarakat desa hutan yang mempunyai perhatian dan berperan mendorong proses optimalisasi serta berkembangnya PHBM, yaitu: Pemerintah Daerah, Lembaga Swadaya Masyarakat (LSM), Lembaga Ekonomi Masyarakat, Lembaga Sosial Masyarakat, Usaha Swasta, Lembaga Pendidikan dan Lembaga Donor. 


\section{Daftar Pustaka}

Nahruddin, Z. (2018). Isu-Isu Strategis Permasalahan Lingkungan Hidup. INA-Rxiv, Open Science Framework.

Sabila, Ayu Novawana, dkk. Implementasi program pengelolaan hutan bersama masyarakat dalam mewujudkan sustainable development masyarakat desa hutan. Jurusan Administrasi Publik, Fakultas IImu Administrasi, Universitas Brawijaya Malang.

Supono. (2017). Pengelolaan Sumber Daya Hutan Bersama Masyarakat (PHBM) Perum Perhutani Sebagai Implementasi Tanggung Jawab Perusahaan. HIm, 132. Genta Press: Yogyakarta.

Prawestya Tunggul Damayatanti. (2011). Upaya pelestarian hutan melalui pengelolaan sumberdaya hutan bersama masyarakat. MA Al-Ikhlas Blora Jawa Tengah, Indonesia. 